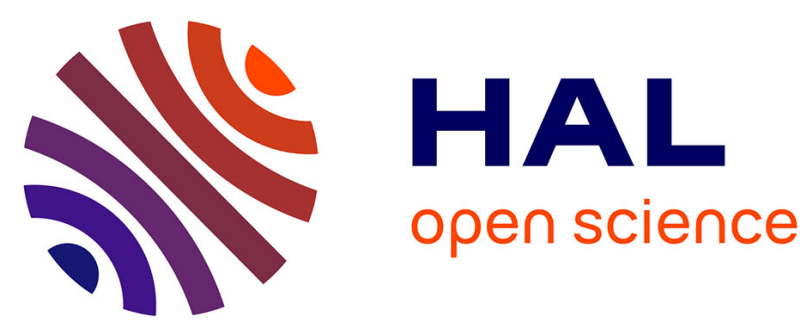

\title{
Coacervates of whey proteins to protect and improve the oral delivery of a bioactive molecule
}

\author{
Anne Laure Chapeau, Nicolas Bertrand, Valérie Briard-Bion, Pascaline
}

Hamon, Denis Poncelet, Said Bouhallab

\section{To cite this version:}

Anne Laure Chapeau, Nicolas Bertrand, Valérie Briard-Bion, Pascaline Hamon, Denis Poncelet, et al. Coacervates of whey proteins to protect and improve the oral delivery of a bioactive molecule. Journal of Functional Foods, 2017, 38, pp.197-204. 10.1016/j.jff.2017.09.009 hal-01593201

\section{HAL Id: hal-01593201 \\ https://hal.science/hal-01593201}

Submitted on 25 Sep 2017

HAL is a multi-disciplinary open access archive for the deposit and dissemination of scientific research documents, whether they are published or not. The documents may come from teaching and research institutions in France or abroad, or from public or private research centers.
L'archive ouverte pluridisciplinaire HAL, est destinée au dépôt et à la diffusion de documents scientifiques de niveau recherche, publiés ou non, émanant des établissements d'enseignement et de recherche français ou étrangers, des laboratoires publics ou privés. 


\title{
Coacervates of whey proteins to protect and improve the oral delivery of a bioactive molecule
}

\author{
Anne-Laure Chapeau ${ }^{\mathrm{a}, \mathrm{b}, \mathrm{c}}$, Nicolas Bertrand ${ }^{\mathrm{b}, \mathrm{d}, *}$, Valérie Briard-Bion ${ }^{\mathrm{a}}$, Pascaline Hamon ${ }^{\mathrm{a}}$, Denis Poncelet $^{\mathrm{c}}$, \\ Saïd Bouhallab ${ }^{\mathrm{a}, *}$ \\ a STLO, UMR1253, INRA, Agrocampus Ouest, 35000 Rennes, France \\ ${ }^{\mathrm{b}}$ Faculty of Pharmacy, CHU de Quebec Research Center, Université Laval, G1V 4G2 Québec City, Canada \\ ' ONIRIS, UMR CNRS GEPEA 6144, 44322 Nantes, France \\ ${ }^{\mathrm{d}}$ Institute of Nutrition and Functional Foods INAF, G1V 0A6 Quebec City, Canada
}

\section{A R T I C L E I N F O}

\section{Article history:}

Received 27 May 2017

Received in revised form 7 September 2017

Accepted 7 September 2017

\section{Keywords:}

Vitamin B9

Encapsulation

Protection

Pharmacokinetic

Bioavailability

Formulation

\begin{abstract}
A B S T R A C T
The potentiality of heteroprotein complex coacervates as biocarrier for a bioactive was investigated. Vitamin B9 (B9), also known as folic acid, was encapsulated by complex coacervation of two whey proteins (WP), $\beta$-lactoglobulin and lactoferrin. The stability and bioavailability of formed B9-WP coacervates was then characterized. Under degradative conditions in vitro (UV light irradiation, and oxidation by $\mathrm{H}_{2} \mathrm{O}_{2}$ ), WP coacervates protected the vitamin against chemical degradation. B9-WP coacervates also showed considerable physical stability over time when incorporated in real food matrices. Compared to unencapsulated B9, oral administration of B9-WP coacervates to healthy rats enhanced the plasma level of the vitamin. This improved bioavailability can be ascribed to the improvement in the solubility of B9 throughout the gastro-intestinal tract. We thus demonstrate the efficiency of WP coacervates as biocarrier for the protection and delivery of small bioactive molecules.
\end{abstract}

(c) 2017 Elsevier Ltd. All rights reserved.

\section{Introduction}

In recent years, the interest in functional foods and nutraceuticals has been motivated by their potential to contribute to healthy lifestyles. Their ability to enhance the daily intakes of specific nutrients and prevent deficiencies can possibly reduce the risks of certain diseases. (Annunziata \& Vecchio, 2011). To formulate functional foods, bioactive molecules like minerals, antioxidants, omega-3 fatty acids or vitamins can be incorporated into food matrices (de Boer, Urlings, \& Bast, 2016). Yet, in industrial settings where processes and storage can affect stability, solubility and bioavailability, the incorporation of these molecules and the preservation of their biological properties remain challenging. In this context, encapsulating agents can act as carriers or delivery systems to overcome these limitations (Shimoni, 2009). To ensure

* Corresponding authors at: STLO, UMR1253, INRA, Agrocampus Ouest, 65, rue de Saint Brieuc, F-35042 Rennes, France (S. Bouhallab). Faculty of Pharmacy, CHU de Quebec Research Center, Université Laval, G1V 4G2 Québec City, Canada (N. Bertrand).

E-mail addresses: anne-laure.chapeau@inra.fr (A.-L. Chapeau), nicolas.bertrand@pha.ulaval.ca (N. Bertrand), valerie.briard-bion@inra.fr (V. Briard-Bion), pascaline.hamon@inra.fr (P. Hamon), denis.poncelet@oniris-nantes.fr (D. Poncelet), said.bouhallab@inra.fr (S. Bouhallab). industrial sustainability, such systems should be developed from natural food-grade ingredients while using economical and reliable raw materials and processes (McClements, Decker, Park, \& Weiss, 2009). The design of natural food-grade carriers, thereafter called "biocarriers" represents an important source of innovation for current food technologies. By evaluating how coacervates prepared from whey proteins can increase the stability and bioavailability of a model bioactive molecule, the present study highlights important parameters for a promising technology.

Among standard food components, edible proteins are good candidates for the design of natural biocarriers. Proteins are generally recognized as safe (GRAS) by the food industry and display unique functional properties such as their ability to form gels, to spontaneously self-assemble or to bind specific ligands. These characteristics make them ideal materials for the encapsulation of bioactive molecules (Chen, Remondetto, \& Subirade, 2006; Christophe Schmitt, Sanchez, Desobry-Banon, \& Hardy, 1998). While supplying essential amino-acids and providing nutritional benefits, some food proteins exhibit additional and specific bioactive properties. For instance, lactoferrin an iron-binding glycoprotein is described as a natural modulator of the immune system (Farnaud \& Evans, 2003) and beta-lactoglobulin has demonstrated interesting binding abilities for bioactives such as curcumin 
(Sneharani, Karakkat, Singh, \& Rao, 2010), essential fatty acids (Loch et al., 2013) or polyphenols (Zorilla, Liang, Remondetto, \& Subirade, 2011).

Several encapsulation techniques exist that use food proteins as building blocks for the preparation of biocarriers (Matalanis, Jones, \& McClements, 2011). Among them, the complex coacervation of biopolymers has demonstrated interesting properties; the process offers high loading efficiency (up to 99\%) and good control over the release of bioactives, through mechanical stress, temperature or passive diffusion (Gouin, 2004). Most systems currently studied rely on the complex coacervation between proteins and polysaccharides (Garti \& McClements, 2012; Turgeon, Schmitt, \& Sanchez, 2007). The use of complex coacervates involving only proteins is less described and might be an attractive alternative in the context of clean label foods.

The formation of biocarriers throughout complex coacervation of a protein-protein system, named heteroprotein complex coacervation, is a two-step process. First, the bioactive is incorporated in a solution of protein A. Next, a solution of protein B, carrying opposite electric charges, is added to the system. Driven by electrostatic interactions between the two proteins, complex coacervation occurs, resulting in the formation of supramolecular coassemblies of the two proteins called coacervates, entrapping the bioactive. As coarcervation is mainly driven by electrostatic interactions, the nature of the proteins, their stoichiometric ratios, as well as the $\mathrm{pH}$ and ionic strength of the solutions all strongly affect the coacervation process (Croguennec, Tavares, \& Bouhallab, 2016; Schmitt \& Turgeon, 2011). Thus, the optimal choice of proteins and the methods for heteroprotein complex coacervation are still under investigation to maximize the efficiency and benefits of the encapsulation process.

Recently the coacervation of two whey proteins, betalactoglobulin (BLG) and lactoferrin (LF), have been investigated in details (Anema \& de Kruif, 2014; Flanagan et al., 2015; Tavares, Croguennec, Hamon, Carvalho, \& Bouhallab, 2015; Yan et al., 2013). Beyond their ability to form coacervates, whey proteins display other features that are interesting from industrial and physicochemical standpoints. First, they are common by-products of the dairy industry: finding differentiated uses and functionalities for them could contribute to their industrial valorization. Second, whey proteins demonstrate interesting binding properties with various bioactive molecules. For instance, BLG can bind many small bioactives as indicated above and LF is able to bind several molecules of vitamin B9 (Tavares et al., 2015). Such proteins-ligands interactions can be exploited to encapsulate a variety of bioactives. Finally, consumers seem to favor foods with minimal amounts of additives, closer to natural products. In this regard, the preparation of biocarriers using milk components could pave the way for "clean-label" or "green product" functional foods and dairy products (Diaz, 2013). Altogether, efficiently exploiting whey protein's coacervates for encapsulation could elegantly complement alginates, gums, kappa-carrageenans and other biopolymers used in the food industry (Tavares, Croguennec, Carvalho, \& Bouhallab, 2014).

We recently described the optimal conditions for optimal encapsulation of a model bioactive, vitamin B9 (B9) by BLG-LF coacervates (Chapeau et al., 2016). B9 is involved in several important biochemical processes, notably DNA synthesis and repair (Adank, Green, Skeaff, \& Briars, 2003; Lucock, 2000). Since it is not synthetized by the human metabolism, B9 must be found in sufficient quantity in the daily diet (Basset, Quinlivan, Gregory, \& Hanson, 2005). Certain populations, like pregnant women and elderly people, are more vulnerable to deficiencies (Mills \& Signore, 2004) and could benefit from food enriched with B9 (Gregory, 2001). This represents a technological challenge since $\mathrm{B} 9$, as many other bioactives, is poorly soluble in acidic aqueous solutions. Moreover the relative instability and precipitation of B9 in some food matrices and in the gastro-intestinal tract might comprise its overall oral bioavailability (McNulty \& Pentieva, 2004). The encapsulation of B9 in biocarriers might therefore provide an interesting alternative to enrich acidic foods while preserving the bioavailability of the vitamin.

Building on previous work which optimized the coacervation of whey proteins at the bench scale level (Chapeau et al., 2017), the present study validates how the encapsulation of B9 can contribute to its physicochemical stability and increase its bioavailability. To progress toward the complete formulation of an efficient biocarrier, we investigated here (i) the protective properties of the coacervates under different stresses occurring during storage or transformation processes (UV-light radiations and oxidation), (ii) the stability of B9-loaded coacervates in food matrices, and (iii) the ability of the coacervates to promote the gastrointestinal absorption of B9 in rats.

\section{Material and methods}

\subsection{Stock solutions}

B9 stock solutions at $1 \mathrm{~g} / \mathrm{L}$ were prepared by solubilizing folic acid powder (purity $>97 \%$, Sigma Aldrich, St. Louis, MO, USA) in aqueous $\mathrm{NaOH}$ solution $(\mathrm{pH}>8)$. The $\mathrm{pH}$ was adjusted to $\mathrm{pH} 5.5$ using $1 \mathrm{M} \mathrm{HCl}$ solution. This $\mathrm{pH}$ value was found to be optimal for complex coacervation between the two whey proteins (Chapeau et al., 2016). The prepared B9 solution was centrifuged at $28,000 \mathrm{~g}$ for $30 \mathrm{~min}$ at room temperature (centrifuge Heraeus Biofuge Primo, Thermo Scientific, Waltham, MA, USA) to remove the insoluble fraction of B9. The exact vitamin B9 concentration was determined by absorbance at $283 \mathrm{~nm}$ (spectrometer UVmc2, Safas, Monaco) using $25.1 \mathrm{~L} \cdot \mathrm{g}^{-1} \cdot \mathrm{cm}^{-1}$ as the extinction coefficient.

BLG (confidential industrial source) was further purified before use. BLG powder was dispersed in deionized water $(45 \mathrm{~g} / \mathrm{L})$, adjusted to $\mathrm{pH} 4.6$ with $1 \mathrm{M} \mathrm{HCl}$, and kept at $30^{\circ} \mathrm{C}$ for 5 min to precipitate non-native forms of BLG. The dispersion was centrifuged at $20,000 \mathrm{~g}$ for $10 \mathrm{~min}$ at room temperature. The BLG suspension was then freeze-dried and stored at $-20{ }^{\circ} \mathrm{C}$ until use. LF from bovine milk (purity $90 \%$ and iron saturation level of $10-20 \%$, Fonterra Cooperative Group, New Zealand) was used without further purification. LF and BLG stock solutions were prepared by solubilizing protein powders in ultrapure water adjusted to $\mathrm{pH} 5.5$ using $1 \mathrm{M}$ $\mathrm{HCl}$. The exact protein concentrations of LF and BLG (16.6 and $18.3 \mathrm{~g} / \mathrm{L}$, respectively) were determined by absorbance at $280 \mathrm{~nm}$ (spectrometer UVmc ${ }^{2}$, Safas, Monaco) using $0.96 \mathrm{~L} \cdot \mathrm{g}^{-1} \cdot \mathrm{cm}^{-1}$ and $1.47 \mathrm{~L} \cdot \mathrm{g}^{-1} \cdot \mathrm{cm}^{-1}$ as extinction coefficients, respectively.

\subsection{Preparation of B9-whey proteins coacervates}

Coacervates of B9 and whey proteins (B9-WP) were prepared according to the previous study that defined the B9 and WP concentration ranges and B9:WP optimal ratios for complex coacervation (Chapeau et al. (2017). Briefly, a solution containing $0.11 \mathrm{~g} / \mathrm{L}$ of B9 and $4.15 \mathrm{~g} / \mathrm{L}$ of LF was prepared, and equilibrated for $10 \mathrm{~min}$, at room temperature. Then, an equivalent volume of the BLG solution was added (final BLG concentration of $9.15 \mathrm{~g} / \mathrm{L}$ ). Spontaneous coacervation occurred at $\mathrm{pH} 5.5$ without significant $\mathrm{pH}$ change after mixing. The B9-WP coacervate phase was recovered by centrifugation at $38,000 \mathrm{~g}$ for $45 \mathrm{~min}$ at $20^{\circ} \mathrm{C}$ (Centrifuge Avanti J-26S XP, Beckman Coulter Inc., Brea, CA 92821 USA). The recovered pellet had a final protein concentration of $26 \% \mathrm{w} / \mathrm{w}$, with a $2: 1$ ratio of BLG to LF, and a final B9 loading of $0.04 \% \mathrm{w} / \mathrm{w}$ and at $\mathrm{pH} 5.5$. Coacervates of the two whey proteins without B9 were also prepared and used as control when required. 


\subsection{Photodegradation}

\subsubsection{Method}

Photodegradation was induced according to a method adapted from (Akhtar, Khan, \& Ahmad, 1999). A Philips 30 W TW tube was used to expose experimental solutions to UV-light radiation, simulating a daylight exposure. The UV tube emits $88.7 \%$ of its radiation energy at $254 \mathrm{~nm}$, corresponding to one of the absorption maxima $(256 \mathrm{~nm})$ of B9.

The experimental solutions contained B9 at $0.4 \mathrm{~g} / \mathrm{L}$ alone, in combination with LF $(4.15 \mathrm{~g} / \mathrm{L})$ or as B9-WP coacervates (as described above). Aliquots of $500 \mu \mathrm{L}$ in $1.5 \mathrm{~mL}$ microcentrifuge tubes were irradiated with UV-light, while controls were kept in the dark, at $20^{\circ} \mathrm{C}$. After $0,8,24$ or $48 \mathrm{~h}$, two aliquots of each solutions were withdrawn and analyzed by reverse-phase high performance liquid chromatography (RP-HPLC), and mass spectrometry analysis.

\subsubsection{RP-HPLC analysis}

B9 and derived products were analyzed by reversed-phase high-performance liquid chromatography (RP-HPLC). Briefly, FA was separated on a PLRPS column (S/N 1006329-5, Varian Inc., Shropshire, UK) connected to a Waters 2695 HPLC system. Elution was performed using a gradient of solvent (acetonitrile $80 \%$, water $20 \%$, trifluoroacetic acid $0.1 \%$ ) in water containing $0.1 \%$ trifluoroacetic acid. Detection was performed by absorbance at $283 \mathrm{~nm}$. B9 degradation products, P-aminobenzoylglutamic acid (Pa) and a Pteridine residue $(\mathrm{Pr})$, were identified by mass spectrometry as described below.

\subsubsection{Mass spectrometry analysis}

Electrospray mass spectrometer operating in positive ion mode with a voltage of $4 \mathrm{kV}$ one-line with RP-HPLC was used for the identification of B9 degradation products. Spectra were recorded in full MS mode and selected in a mass range $130-2000 \mathrm{~m} / \mathrm{z}$ for MS spectra with a resolution of 70,000 at $\mathrm{m} / \mathrm{z} 200$. The instrument was externally calibrated according to the supplier's instructions. Ions recovered in the sample were analyzed from the MS spectra using Xcalibur 2.2 Software (Thermo Scientific, San Jose, USA). The specific ions of B9 and its photoproducts, Pr and Pa, were identified by their respective molecular weights: $\mathrm{B9}(\mathrm{Mw}=442 \mathrm{Da}), \mathrm{Pr}$ $(\mathrm{Mw}=267 \mathrm{Da})$ and $\mathrm{Pa}(\mathrm{Mw}=192 \mathrm{Da})$ (Patring \& Jastrebova, 2007; Santos, Scurachio, \& Cardoso, 2014). The relative abundance of various species after treatments was estimated from the intensity of their corresponding ions before and after treatment. Experiments were conducted in triplicates.

\subsection{Oxidative degradation}

Oxidative degradation was induced by exposure to hydrogen peroxide $\left(\mathrm{H}_{2} \mathrm{O}_{2}\right)$. Experimental solutions containing $1 \mathrm{~g} / \mathrm{L}$ of $\mathrm{B9}$ alone or as or as B9-WP coacervates were prepared. Solutions of B9 $(1 \mathrm{~g} / \mathrm{L})$ with either $\mathrm{LF}(27.8 \mathrm{~g} / \mathrm{L})$ or BLG $(55.2 \mathrm{~g} / \mathrm{L})$ were also used. In each solution, $\mathrm{H}_{2} \mathrm{O}_{2}(30 \% \mathrm{v} / \mathrm{v}$, Sigma Aldrich, St. Louis, MO, USA) was added to reach final concentrations of $0.33 \mathrm{~g} / \mathrm{L}$ B9 and $20 \%(\mathrm{v} /$ v) $\mathrm{H}_{2} \mathrm{O}_{2}$. Samples were incubated at $37^{\circ} \mathrm{C}$ in the dark. At $0,2,4,6$, and $18 \mathrm{~h}$ after the addition of $\mathrm{H}_{2} \mathrm{O}_{2}$, the remaining residual concentration of $\mathrm{B} 9$ in the solution were quantified by the enzyme linked immune assay (ELISA) method. Experiments were conducted in triplicates.

\subsection{B9 quantification by enzyme-linked immunosorbent assay}

Concentrations of B9 were determined using a competitive ELISA (Vitamin B9 Elisa Kit 96T, Abbexa, Cambridge, UK). Each sample was analyzed in technical duplicates (with no dilution or a 0.5 dilution in Abbexa kit diluent buffer). Appropriately diluted samples $(50 \mu \mathrm{L})$ were added into each well of the microplate precoated with B9. Then, $50 \mu \mathrm{L}$ of biotinylated anti-B9 antibodies were added into each well. The microplate was incubated for 45 min à $37^{\circ} \mathrm{C}$, then washed three times with the Abbexa washing solution. Then, $100 \mu \mathrm{L}$ of horseradish peroxidase (HRP) streptavidin solution was added into each well, followed by incubation for $30 \mathrm{~min}$ à $37^{\circ} \mathrm{C}$. The microplate was washed five times with the washing solution. For quantification, $90 \mu \mathrm{L}$ of tetramethylbenzidine substrate was added into each well and the microplate was incubated for $15 \mathrm{~min}$ in the dark at $37^{\circ} \mathrm{C}$. The reaction was stopped by the addition of $50 \mu \mathrm{L}$ of Abbexa stop solution. Finally, the absorbance of each well was measured at $450 \mathrm{~nm}$ using a spectrophotometer microplate reader (NanoQuant infinite M200 Pro, Tecan, Switzerland). For each analysis, a calibration curve was performed over the range of 1000 to $12.5 \mathrm{ng} / \mathrm{mL}\left(R^{2}>0.98\right)$. Under these experimental conditions, the limit of quantification of this method was calculated to be $7.5 \mathrm{ng} / \mathrm{mL}$.

\subsection{Stability of B9-WP coacervates as assessed by dialysis method}

Dialysis method was set up to explore the stability and release behavior of B9 from the B9-WP coacervates when incorporated into a dairy product such as milk. Two processed milk samples were used: Ultra High Temperature (UHT) semi skimmed milk (Sodiaal, France) and pasteurized whole milk (Québon, Canada). Each of the two types of milk was enriched by the addition of free B9, B9-WP coacervates or free B9 and additional WP coacervates. Suspension was made using threerepeated ultrasonication cycles of $1 \mathrm{~min}$ (ultrasonication bath Bransonic 220, Branson Ultrasonics, St Louis, USA) followed by 2 min of vortex (Topmix-94223, Fisher Scientific Bioblock, Whaltam, USA).

To ascertain stability in enriched milks, $5 \mathrm{~mL}$ of milk samples with added B9 $(50 \mathrm{mg} / \mathrm{L}$ of B9) were placed in a $5-\mathrm{cm}$ long cellulose-ester dialysis tubing with a molecular weight cut-off of 100 kDa (Spectra/Por product, Spectrum Laboratories, Inc., USA). Dialysis experiments were performed under constant slow agitation in the dark and at $4{ }^{\circ} \mathrm{C}$ against two liters of corresponding milk. B9 concentration inside the dialysis membrane was monitored by ELISA method at 0, 1, 2, 4, 8 and $24 \mathrm{~h}$. Each experiment was carried in triplicate.

The $\mathrm{B} 9$ released from the dialysis bag was calculated using the following equation:

$$
B 9 \text { release }(\%)=\left(1-\frac{[B 9]_{t}}{[B 9]_{0}}\right) \times 100
$$

where $[\mathrm{B} 9]_{\mathrm{t}}$ represents the concentration inside the dialysis bag at time $t$, and $[\mathrm{B} 9]_{0}$, the initial concentration. The absence of interference from the dairy matrices on the ELISA quantification was checked prior to the experiments.

\subsection{Phase contrast microscopy}

B9-WP coacervates suspended in ultrafiltered milk permeate were observed by a phase contrast optical microscope (Olympus BX51TF, Olympus, Hamburg, Germany) set at the magnification of $\times 40$ or $\times 100$. A $10 \mu \mathrm{L}$ sample of the B9-WP coacervates dairy solution was deposed on standard microscope glass slide, covered by a glass coverslip ( $22 \mathrm{~mm} \times 22 \mathrm{~mm}$ ) and immediately observed. The samples and observations were performed three times to ensure the representability of the results. 


\subsection{In vivo pharmacokinetic studies in male rats}

\subsubsection{Ethics}

All experiments were performed in accordance with the Canadian Council on Animal Care and were approved by the Institutional Committee of the CHU de Quebec Research Center (CHUL) (protocol number 2015074-2).

\subsubsection{Tested solutions}

The four solutions used in this experiment were prepared by dissolving B9, BLG and LF or B9-WP coacervates in PBS. The concentration of B9 in all solutions was set at $1 \mathrm{~g} / \mathrm{L}$, while the concentrations of BLG and LF were 55.2 and $27.8 \mathrm{~g} / \mathrm{L}$, respectively. Coacervates contained both proteins at these concentrations.

\subsubsection{Pharmacokinetic studies}

Pharmacokinetic studies were performed in male Sprague Dawley rats (350-450 g) obtained from Charles River (St-Constant, QC, Canada) and housed in $12 \mathrm{~h}$ light/dark cycles at $20 \pm 2{ }^{\circ} \mathrm{C}$ and 55$60 \%$ relative humidity. Prior to the experiment, animals were fed ad libitum for a minimum of 10 days with a folic acid deficient diet (TD 95247, Envigo Teklad Diets, Madison Wisconsin, USA) and free access to drinking water. For the experiment, rats were randomly divided into 4 groups of 5 animals each. Each group was administrated a specific PBS solution: B9, B9-WP coacervates, B9 and BLG or B9 and LF. Each animal received a dose of $500 \mu \mathrm{g}$ of B9. Solutions were administered using a blunt needle via the esophagus into the stomach. Just before the oral administration $(0 \mathrm{~min})$ and at different times post administration $(0.5,1,2,4,6$ and $10 \mathrm{~h}), 200 \mu \mathrm{L}$ blood samples were collected via the saphenous vein using capillary tubes (Microvette CB300K2E, Sarstedt, Germany). Blood samples were centrifuged at $2000 \mathrm{rcf}$ for $15 \mathrm{~min}$ at $4{ }^{\circ} \mathrm{C}$, and the isolated plasma was kept in microcentrifuge tubes at $-20^{\circ} \mathrm{C}$ until further analysis (5-7 days). Concentrations of $\mathrm{B} 9$ recovered in rat plasma were determined by ELISA.

\subsubsection{Pharmacokinetic parameters}

The maximal $\mathrm{B} 9$ concentration in rat plasma $\left(\mathrm{C}_{\max }\right)$ and the time taken to reach $C_{\max }\left(T_{\max }\right)$ were obtained from experimental data. The area under the plasma concentration $v s$. time curve from time 0-10 h (AUC) was calculated using the trapezoidal method.

\subsubsection{Statistical analysis}

A series of ANOVA followed by post hoc Tuckey tests were performed to investigate potential statistical differences between the pharmacokinetic parameters. In all cases, $\mathrm{p}<0.05$ was considered to be statistically significant.

\section{Results}

\subsection{Protective effect of B9-WP coacervates}

To investigate the ability of WP coacervates to limit the degradation of B9, unencapsulated B9, mixtures of B9 with LF and BLG and B9-WP coacervates were exposed to either UV-light (photodegradation) or $\mathrm{H}_{2} \mathrm{O}_{2}$ (oxidative degradation). These accelerated degradation conditions provided surrogates for processes occurring during food transformation or long time storage. B9 and LF mixture was studied because we recently showed that B9 forms nanocomplexes with LF (Tavares et al., 2015).

\subsubsection{Photodegradation}

In aqueous environments, UV-light converts B9 into two main photoproducts, a pteridine residue $(\mathrm{Pr})$ and a $\mathrm{P}$ aminobenzoylglutamic acid (Pa), with the capture of a water mole- cule according to the following chemical scheme [1] (Jamil Akhtar, Ataullah Khan, \& Ahmad, 2003; Off et al., 2005):

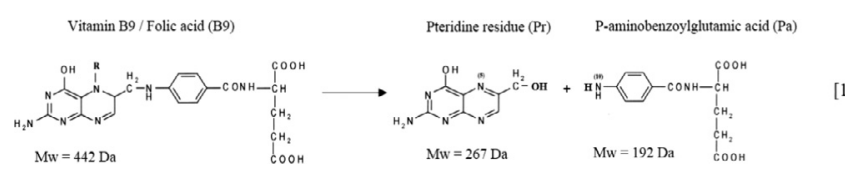

Fig. 1 shows the elution profiles of B9 of the three treated samples after exposure to UV light for 0,8 or $24 \mathrm{~h}$. On shown, native B9 had a retention time of 3.3 min (Fig. $1 \mathrm{~A}-\mathrm{C}$ ). When $\mathrm{B9}$ was not encapsulated (i.e., solutions of B9 alone or in complex with LF), degradation products were evidenced after $8 \mathrm{~h}$ of irradiation with the apparition of a peak with a retention time of $2.7 \mathrm{~min}$. The rel-
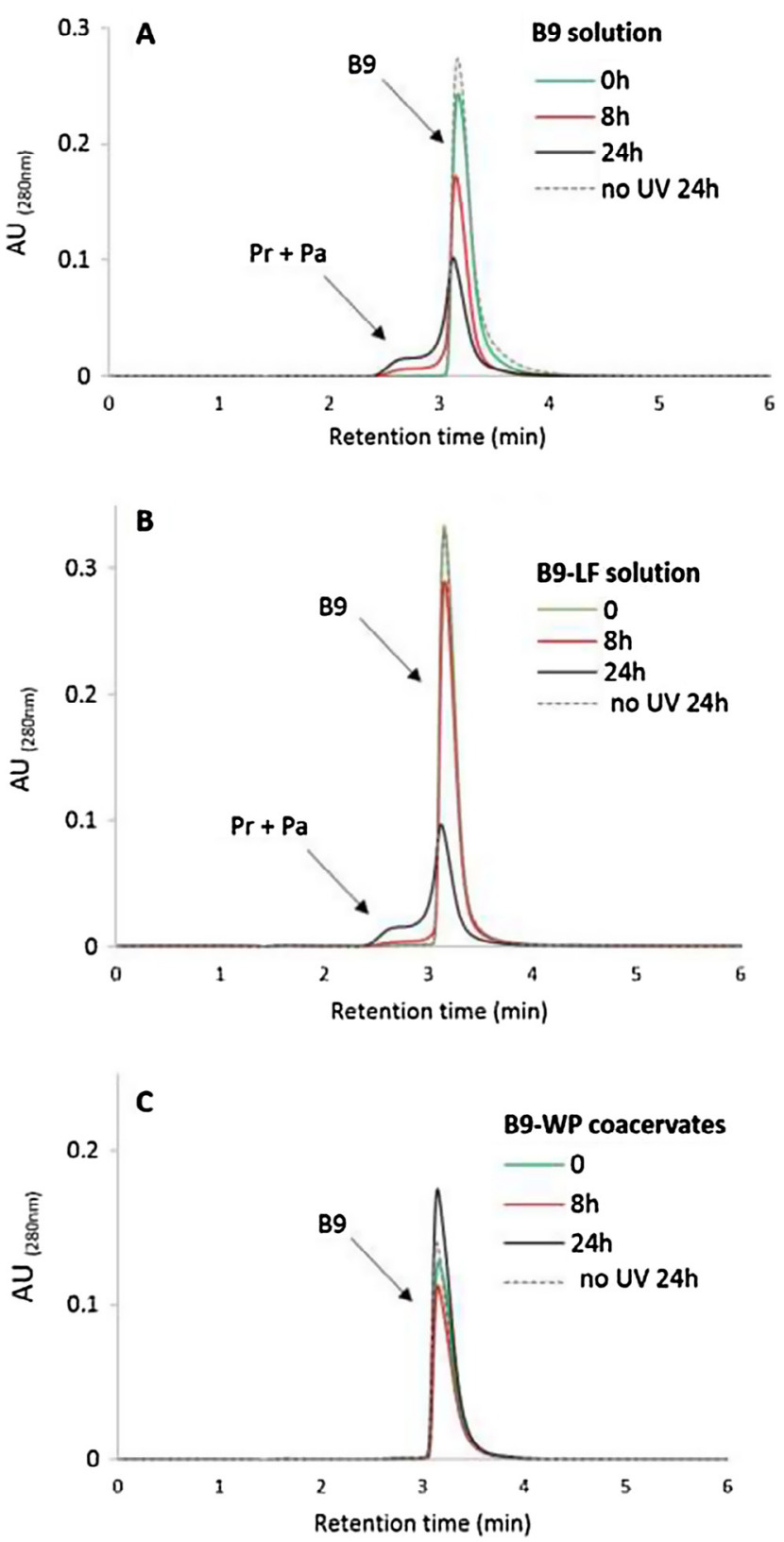

Fig. 1. Evolution of RP-HPLC profiles of vitamin B9 after exposure to UV light during $24 \mathrm{~h}$. Vitamin B9 was treated with UV either alone in solution (A), pre-complexed with lactoferrin (B) or encapsulated in whey protein coacervates (C). 


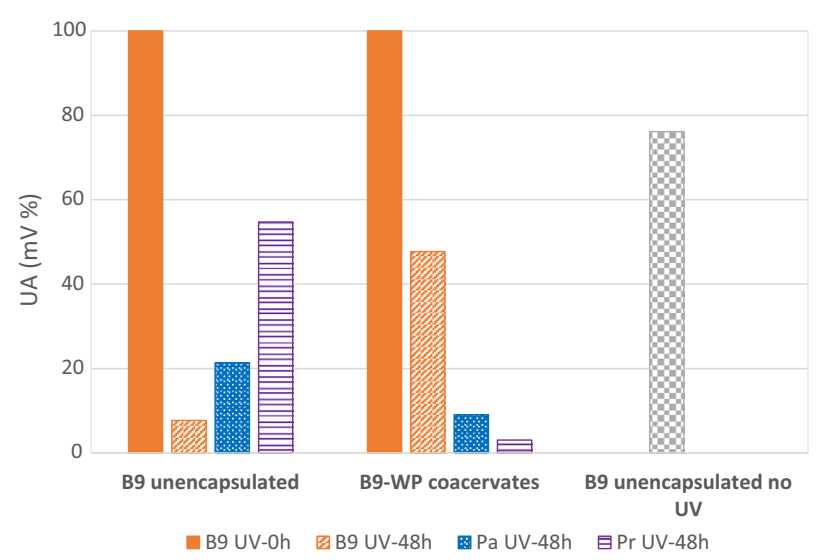

Fig. 2. Protective effect of WP coacervates against UV light induced degradation of vitamin B9 as assessed by mass spectrometry. Ion intensities of B9 and derived products from electrospray mass spectrometry analysis before and after $48 \mathrm{~h}$ exposure to UV light. The intensity of untreated B9 after $48 \mathrm{~h}$ is also shown. Under used conditions, experimental variations were $\leq 5 \%$.

ative abundance of this peak increased after $24 \mathrm{~h}$ of irradiation for treated B9 alone or in complex with LF with concomitant decrease of B9 peak (Fig. 1A, B). Mass spectrometry indicated the presence of ions with molecular masses, $m / z$ of 442,267 , and 192 corresponding to $\mathrm{B} 9$ and its two main degradation products $\mathrm{Pr}$ and $\mathrm{Pa}$, respectively. In the absence of UV light, these two ions were not detected suggesting that they origin from the photodegradation of B9. The formation of these products from B9 has been already reported by Santos et al. (2014). Interestingly, when B9 was encapsulated in WP coacervates, the two degradation products were not detected (Fig. 1C), suggesting the WP coacervates can mitigate the degradation of B9 induced by UV light.

An estimation of the relative degradation of B9 alone or protected in WP coacervates with and without UV irradiation was assessed by mass spectrometry analysis ((Fig. 2). Based on the initial ion intensity, about $90 \%$ of free B9 disappeared after $48 \mathrm{~h}$ under UV light with simultaneous appearance of degradation products $\mathrm{Pr}$ and $\mathrm{Pa}$ (see the scheme above). Meanwhile, despite a slight decrease in B9 ion intensity, the untreated B9 solution stored in the dark was relatively stable (Fig. 2). Encapsulation into WP coacervates limited the observed degradation of B9. More than $50 \%$ of initial B9 (initial ion intensity) were still detected after $48 \mathrm{~h}$ of UV light treatment. This was also confirmed by a lower detection of the ions corresponding to the degradation products Pr and Pa.

\subsubsection{Oxidative degradation}

Hydrogen peroxide was used to accelerate oxidative degradation, an efficient method to study drug decomposition in pharmaceutical sciences (Blessy, Patel, Prajapati, \& Agrawal, 2014). Fig. 3 presents the remaining quantities of B9 in solutions (B9 alone or in complex with LF) and encapsulated into WP coacervates after exposure to $20 \% \mathrm{H}_{2} \mathrm{O}_{2}$, at $37^{\circ} \mathrm{C}$, for $18 \mathrm{~h}$. In these experiments, the ELISA assay allowed quantification of only the native form of B9 (without interference from $\mathrm{H}_{2} \mathrm{O}_{2}$ ). For all the samples, native B9 decreased over time, yet the kinetics were different depending on whether B9 was free, in complex with LF, or encapsulated in WP coacervates. High degradation rate was found for B9 either in free form or in complex with LF. In these samples, degradation of about $75 \%$ on the initial vitamin was found after $18 \mathrm{~h}$ exposure to $\mathrm{H}_{2} \mathrm{O}_{2}$. Hence, complexation of B9 with LF does not seems to be enough for efficient protection. In contrast, the encapsulated B9 exhibited much slower degradation rate underlying a protective effect.

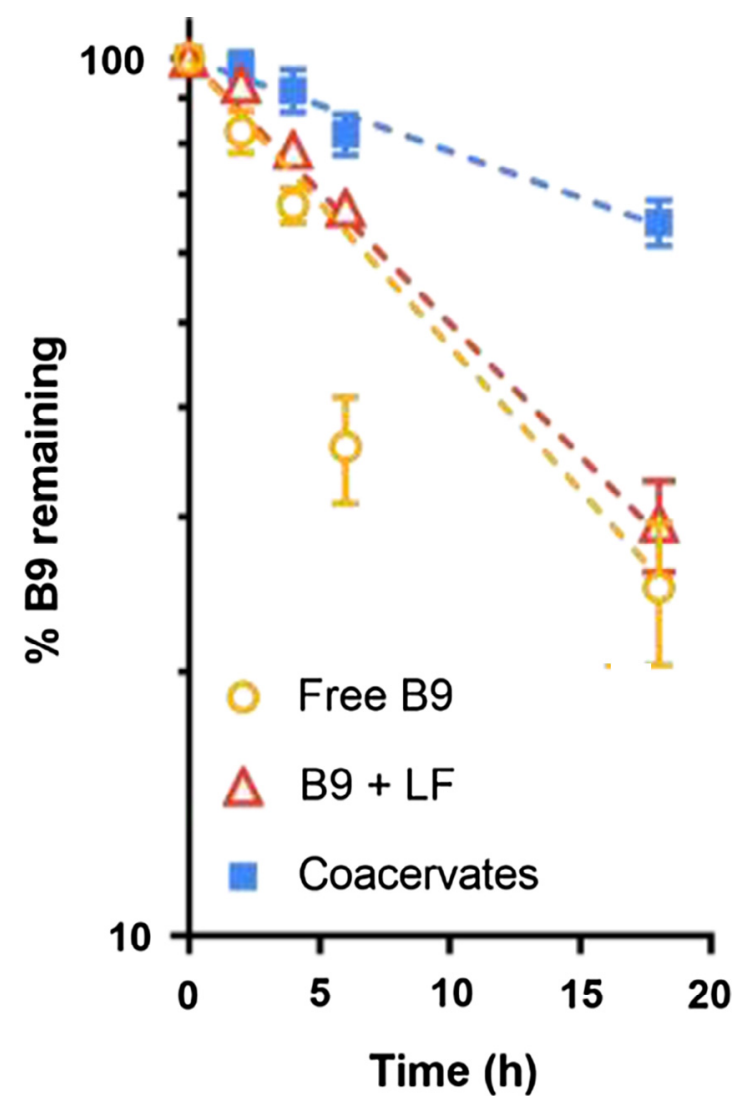

Fig. 3. Comparative degradation kinetics of vitamin B9 either in free form, complexed to Lf or encapsulated into WP coacervates after $18 \mathrm{~h}$ exposure to $20 \%$ hydrogen peroxide at $37^{\circ} \mathrm{C}(n=3$, values represent means \pm SD).

Approximately, 80 and $70 \%$ of the initial B9 into WP coacervates were quantified after 6 and $18 \mathrm{~h}$ of treatment, respectively.

\subsection{Stability of coacervates prepared from WP in dairy solutions}

The ability of the coacervates to maintain interactions with $\mathrm{B9}$ in conditions where other components of food matrices can compete and alter the nature of the protein complexes was checked. Two dairy matrices commonly consumed in North America and Europe were studied: whole full-fat pasteurized milk and UHT semi-skimmed milk. The release of B9 from the coacervates was checked by dialysis approach. Free B9 or B9-WP coacervates were added to milk and submitted to dialysis against the same milk. The free B9 solution is assumed to represent a control sample where the diffusion is only limited by passage through the dialysis membrane (Bertrand, Leclair, \& Hildgen, 2007). In the absence of interactions between B9 and coacervates, for example if the protein complexes are totally disrupted, B9 should be released at rates comparable with the free vitamin solution. The same dialysis results were obtained for the two studied milks.

Encapsulated B9 showed a completely different dialysis behavior as compared to free B9 (Fig. 4). The release of free B9 was nearly complete, i.e. $90-95 \%$ after 24 h of dialysis experiment. Comparatively, the encapsulated B9 seemed to be more retained in the dialysis bag. The release of B9 was then lower and plateaued around $45 \%$ of the initial B9 added to milk indicating a partial stability of B9-WP coacervates. Of note, the effect of the coacervates on the diffusion of B9 was not solely due to the presence of additional WP. In a control experiment, unencapsulated B9 incubated with coacervates prepared in the absence of vitamin, showed a release kinetic similar to that found for free B9. 


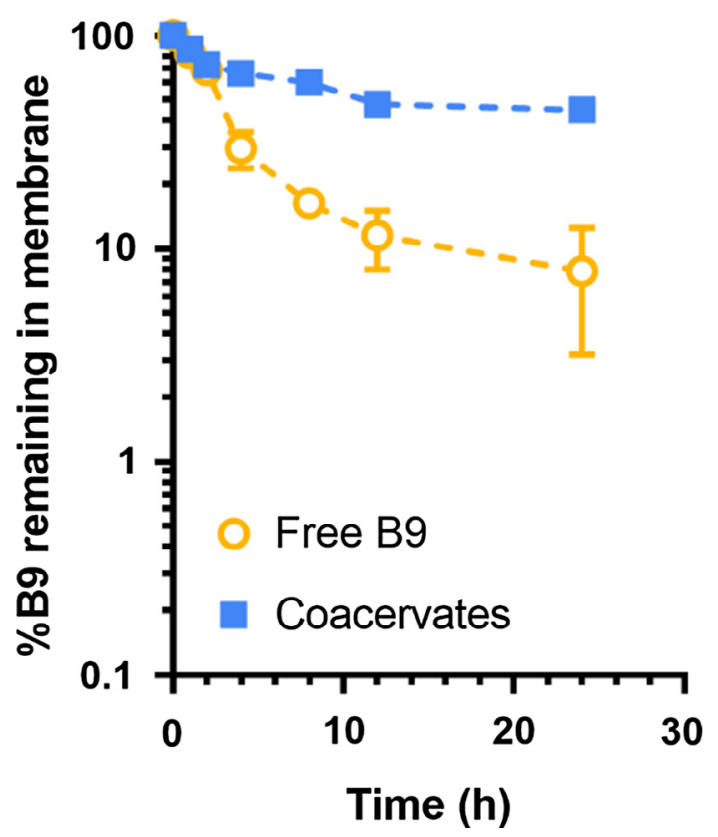

Fig. 4. Kinetic release of B9 from enriched whole pasteurized milk as assessed by dialysis approach. Five $\mathrm{ml}$ of $\mathrm{B} 9$ enriched milk were placed into dialysis tubing and submitted to dialysis against $2 \mathrm{l}$ of unenriched milk for $24 \mathrm{~h}$ at $4{ }^{\circ} \mathrm{C}(\mathrm{n}=3$, values represent means $\pm \mathrm{SD}$ ).

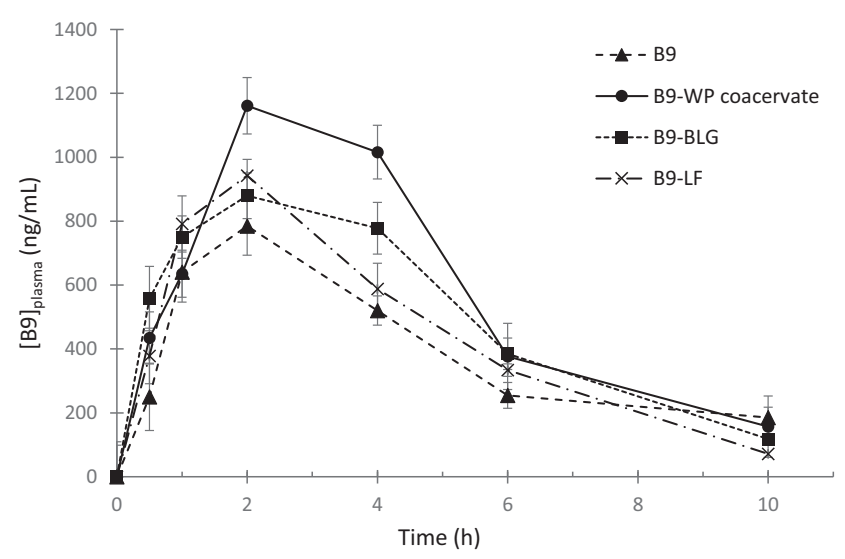

Fig. 5. Pharmacokinetics of vitamin $B 9$ concentrations in rat plasma $v s$ time after a single oral administration at T0 of B9, B9-WP coacervate, B9-BLG, or B9-LF solutions corresponding to a dose of $500 \mu \mathrm{g}$ B9/oral administration. Values represent mean $\pm \mathrm{SD}, \mathrm{n}=5$.

\subsection{In vivo pharmacokinetics of B9-whey proteins coacervates}

Fig. 5 shows the pharmacokinetics of B9 concentrations recovered in plasma after a single oral gavage of rats with either B9 alone, B9 complexed with lactoferrin, B9 in the presence of BLG or encapsulated in WP coacervates. For free B9 group, the B9 level in the plasma of animals increased rapidly during the two first hours post-administration followed by a phase where the detected vitamin decreased slowly until the end of the experiment. The others groups displayed similar profiles. Nevertheless, the plasma level of B9 from B9-WP coacervates was significantly higher than that found for groups receiving free B9. The plasma level of B9 in the other groups (B9 + LF and B9 + BLG) exhibited intermediate levels. Table 1 summarizes the pharmacokinetic parameters $\left(C_{\max }\right.$, $\mathrm{T}_{\max }$, and $\mathrm{AUC}$ ) obtained for each group. Maximum concentrations were obtained within $1.8-3 \mathrm{~h}$ of gavage. The group receiving B9WP coacervates showed the highest $C_{\max }$ value and the largest total blood exposure (i.e., AUC). The B9-WP coacervates group provided a blood exposure which was 1.5 -fold higher than the free B9 solution (5868 vs. $3804 \mathrm{ng} \cdot \mathrm{h} / \mathrm{mL}$ ). Theses parameters were also slightly higher with WP coacervates compared to proteins taken individually at the same concentration.

\section{Discussion}

In this study, B9 was investigated as a model bioactive molecule to illustrate the potential of heteroprotein coacervates for the preparation of biocarriers. Vitamin B9 plays a crucial role in various metabolic and biochemical processes such as the replication of DNA and cell division, notably during the early stages of embryology (Herrmann \& Obeid, 2011; Lucock, 2000). This bioactivity is mostly due to the native form of B9 (Gazzali et al., 2016; Hirakawa, Suzuki, Oikawa, \& Kawanishi, 2003; Patro, Adhikari, Mukherjee, \& Chattopadhyay, 2005). To prepare biocarriers that maintain the bioactivity of the vitamin, it is therefore critical to preserve its chemical integrity.

Under accelerated degradation conditions, unencapsulated free B9 was efficiently converted into various degradation products. B9 can be photo-chemically cleaved, yielding 6-formylpterin and paminobenzoylglutamic acid (Araújo et al., 2015; Thomas, Suárez, Cabrerizo, Martino, \& Capparelli, 2000). This photodegradation preferentially occurs in acidic solutions and in the presence of oxygen (Thomas et al., 2000). Although B9 is known to remain mostly stable in aqueous solution at $37^{\circ} \mathrm{C}$ (Tripet \& Kesselring, 1975; Vora, Riga, Dollimore, \& Alexander, 2002), addition of $\mathrm{H}_{2} \mathrm{O}_{2}$ significantly increases oxidative degradation via the production of singlet oxygen (Gazzali et al., 2016; Thomas et al., 2000). These oxidative conditions allowed degradation of native $\mathrm{B} 9$ forming peteridin product that was identified by mass spectrometry. In our conditions, unencapsulated B9 degraded within a few hours.

Under both UV light irradiation and oxidative conditions, WP coacervates significantly hindered the degradation of B9. After up to $48 \mathrm{~h}$ of exposure to UV light, few degradation products were detected for the encapsulated vitamin, in stark contrast with the degradation observed for free B9. Although small fluctuations in concentrations were observed over time, these differences were similar in samples that were kept in the dark; therefore, these changes can hardly be ascribed to photodegradation. The observed protective effect of the coacervates could be attributed to decreased contact between the vitamin, entrapped in a hydrophobic environment within the proteins, and water or oxygen mole-

Table 1

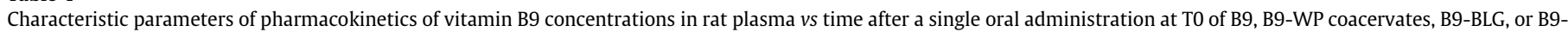
LF solutions corresponding to a dose of $500 \mu \mathrm{g}$ B9/oral administration. Statistical analysis by a, b, c, statistically different at a significance level of $\mathrm{p}<0.05$.

\begin{tabular}{|c|c|c|c|c|c|c|}
\hline & $\begin{array}{l}\mathrm{C}_{\max } \\
(\mathrm{ng} / \mathrm{mL})\end{array}$ & $\begin{array}{l}S D \\
(\mathrm{ng} / \mathrm{mL})\end{array}$ & $\begin{array}{l}\mathrm{T}_{\max } \\
(\mathrm{h})\end{array}$ & $\begin{array}{l}S D \\
(\mathrm{~h})\end{array}$ & $\begin{array}{l}\text { AUC } \\
(\mathrm{ng} \cdot \mathrm{h} / \mathrm{mL})\end{array}$ & $\begin{array}{l}S D \\
(\mathrm{ng} \cdot \mathrm{h} / \mathrm{mL})\end{array}$ \\
\hline B9 & $872^{\mathrm{a}}$ & \pm 49 & 1.8 & \pm 0.3 & $3804^{\mathrm{a}}$ & \pm 190 \\
\hline B9-BLG & $942^{\mathrm{ab}}$ & \pm 95 & 2.8 & \pm 0.3 & $5108^{\mathrm{ab}}$ & \pm 602 \\
\hline B9-LF & $1054^{\mathrm{bc}}$ & \pm 77 & 1.8 & \pm 0.3 & $4516^{\mathrm{ab}}$ & \pm 496 \\
\hline B9-WP coacervates & $1162^{c}$ & 94 & 1.8 & \pm 0.3 & $5868^{\mathrm{b}}$ & \pm 574 \\
\hline
\end{tabular}


cules. About $0.4 \mathrm{~g}$ B9 is protected in a highly concentrated environment, with nearly $260 \mathrm{~g}$ proteins per kg of coacervates. Similar protective effects have been reported for B9 bound to BLG at neutral $\mathrm{pH}$, essentially by decreasing the effective concentration of all reagents involved in the photodecomposition reaction (Liang, Zhang, Zhou, \& Subirade, 2013).

The encapsulation of B9 in WP coacervates also strongly limits its $\mathrm{H}_{2} \mathrm{O}_{2}$ induced oxidation. After $6 \mathrm{~h}$ of oxidative stress, more than twice as much native $\mathrm{B} 9$ was still detectable in the sample containing B9-coacervates compared to free B9. After $18 \mathrm{~h}$, more than 60\% of the initial vitamin remains detectable in the coacervates (compared to less than $30 \%$ for treated free B9). B9-LF complex showed intermediate protective effect toward oxidative degradation, underlying that the WP coacervates present the more efficient protective effect. Once again, the encapsulation of the vitamin within a dehydrated protein complex would limit its reactivity toward the solution containing singlet oxygen. It is also conceivable that the protein could capture singlet oxygen and act as a buffering antioxidant to preserve the vitamin. As such, additional benefit of coacervates could result from the higher concentrations of proteins present in these samples.

Because interactions governing the architecture of protein complexes in the coacervates are non-covalent and could be displaced by proteins, $\mathrm{pH}$ or the higher ionic strength of food matrices, the ability of B9 to remain encapsulated within the coacervates was investigated in milk. Model dialysis experiments where B9coacervates were strongly diluted in milk samples showed that WP complexes retained large part of the vitamin for up to $24 \mathrm{~h}$. The release kinetics of $\mathrm{B} 9$ from the coacervates were found to be similar in whole and semi-skimmed milks. This suggests that B9WP coacervates are stable in food matrices such as milk with complex chemical composition. However, such partial stability requires encapsulation of $\mathrm{B} 9$ into WP coacervates before addition to milk. These results support the benefits and potentiality of WP coacervates as biocarrier of bioactive in complex food products.

Both the protective effect of WP coacervates and their stability in a dairy matrix would be of little scientific merit if the molecule is not bioavailable after oral administration. Pharmacokinetic experiments in rats demonstrated that the encapsulation of B9 in coacervates increased the overall bioavailability of the vitamin, notably by increasing the maximum concentrations measured in blood after a single oral dose. This could be explained by the ability of coacervates to increase the apparent solubility of B9, especially at the acidic $\mathrm{pH}$ values found in the stomach. It has already been reported that the binding between B9 and a whey protein (BLG) can increase the water solubility of the vitamin (Liang \& Subirade, 2010). Since molecules require dissolving to be absorbed through the gastro-intestinal wall, any interactions preventing the precipitation of B9 could be beneficial to increase bioavailability. Similar results were obtained with egg white proteins and B9 (Arzeni, Pérez, LeBlanc, \& Pilosof, 2015), as well as with curcumin and BLG (Teng, Li, \& Wang, 2014), and more generally with many pharmaceutical formulations (Saha, 2010). The intrinsic resistance of BLG to the gastric enzyme pepsin (Mandalari et al., 2009; Reddy, Kella, \& Kinsella, 1988), combined with a rapid proteolysis during duodenal digestion, can increase the bioavailability of B9 during the digestion of B9-BLG complexes (Pérez, David-Birman, Kesselman, Levi-Tal, \& Lesmes, 2014). These observations agree with the present pharmacokinetic data indicating longer times taken to reach maximal concentrations $\left(\mathrm{T}_{\max }\right)$ and potentially delayed adsorption when B9 is administered in presence of BLG alone.

Considering the results obtained in vivo, it is conceivable that proteins, including BLG, LF and coacervates, could protect B9 from gastric degradations. Penalva et al. (2015) suggested that the delayed release of B9 from casein nanoparticles in acidic environ- ment could prevent degradation of the vitamin and improve its oral bioavailability. Herein, the improved protection observed in vitro, added to the differences in pharmacokinetic measured between WP coacervates and simple protein solutions, suggests the WP coacervates architecture provides benefits over plain interactions between vitamin and proteins.

\section{Conclusion}

Herein, coacervates prepared from whey proteins demonstrated their capacity to protect a model bioactive molecule from chemical degradation in vitro and potentiate its bioavailability in vivo. Furthermore, by showing that the B9-coacevates maintain their structural integrity upon addition in a food matrix containing proteins, ions and fat, the potential of the platform for the preparation of enriched food product was evidenced. Because the biocarrier uses whey proteins (lactoferrin and beta-lactoglobulin) which are currently undervalued in the milk transformation industry, the encapsulation approach might have additional merit, from an economic standpoint. Further work, notably incorporating other bioactive molecules, will further position the importance of this encapsulation approach for the preparation of differentiated, natural and additive-free food products.

\section{Acknowledgement}

The authors declare no conflict of interest. They are grateful to Regional councils of Brittany (grant $n^{\circ} 13008651$ ) and Pays de la Loire (grant $n^{\circ}$ 2014-07081) and INRA, France for the financial support of this work through the interregional project PROFIL, supported by BBA industrial association and managed by the "Pôle Agronomique Ouest". Additional funding from the Natural Sciences and Engineering Research Council of Canada (Discovery Grant to N. B.) is also acknowledged.

\section{References}

Adank, C., Green, T. J., Skeaff, C. M., \& Briars, B. (2003). Weekly high-dose folic acid supplementation is effective in lowering serum homocysteine concentrations in women. Annals of Nutrition and Metabolism, 47(2), 55-59. http://dx.doi.org/ 10.1159/000069278.

Akhtar, M. J., Khan, M. A., \& Ahmad, I. (1999). Photodegradation of folic acid in aqueous solution. Journal of Pharmaceutical and Biomedical Analysis, 19(3-4), 269-275. http://dx.doi.org/10.1016/S0731-7085(98)00038-7.

Anema, S. G., \& de Kruif, C. G. (Kees) (2014). Complex coacervates of lactotransferrin and $\beta$-lactoglobulin. Journal of Colloid and Interface Science, 430, 214-220. http://dx.doi.org/10.1016/j.jcis.2014.05.036.

Annunziata, A., \& Vecchio, R. (2011). Functional foods development in the European market: A consumer perspective. Journal of Functional Foods, 3(3), 223-228. http://dx.doi.org/10.1016/j.jff.2011.03.011.

Araújo, M. M., Marchioni, E., Villavicencio, A. L. C. H., Zhao, M., di Pascoli, T., Kuntz, F., \& Bergaentzle, M. (2015). Mechanism of folic acid radiolysis in aqueous solution. LWT - Food Science and Technology, 63(1), 599-603. http://dx.doi.org/ 10.1016/j.lwt.2015.03.038.

Arzeni, C., Pérez, O. E., LeBlanc, J. G., \& Pilosof, A. M. R. (2015). Egg albumin-folic acid nanocomplexes: Performance as a functional ingredient and biological activity. Journal of Functional Foods, 18(Part A), 379-386. http://dx.doi.org/10.1016/j.jff. 2015.07.018.

Basset, G. J. C., Quinlivan, E. P., Gregory, J. F., \& Hanson, A. D. (2005). Folate synthesis and metabolism in plants and prospects for biofortification. Crop Science, 45(2), 449. http://dx.doi.org/10.2135/cropsci2005.0449.

Bertrand, N., Leclair, G., \& Hildgen, P. (2007). Modeling drug release from bioerodible microspheres using a cellular automaton. International Journal of Pharmaceutics, 343(1-2), 196-207. http://dx.doi.org/10.1016/j. ijpharm.2007.05.050.

Blessy, M., Patel, R. D., Prajapati, P. N., \& Agrawal, Y. K. (2014). Development of forced degradation and stability indicating studies of drugs-A review. Journal of Pharmaceutical Analysis, 4(3), 159-165. http://dx.doi.org/10.1016/j. jpha.2013.09.003.

Chapeau, A.-L., Hamon, P., Rousseau, F., Croguennec, T., Poncelet, D., \& Bouhallab, S. (2017). Scale-up production of vitamin loaded heteroprotein coacervates and their protective property. Journal of Food Engineering, 206, 67-76. http://dx.doi. org/10.1016/j.jfoodeng.2017.03.005. 
Chapeau, A.-L., Tavares, G. M., Hamon, P., Croguennec, T., Poncelet, D., \& Bouhallab, S. (2016). Spontaneous co-assembly of lactoferrin and $\beta$-lactoglobulin as a promising biocarrier for vitamin B9. Food Hydrocolloids, 57, 280-290. http://dx. doi.org/10.1016/j.foodhyd.2016.02.003.

Chen, L. Y., Remondetto, G. E., \& Subirade, M. (2006). Food protein-based materials as nutraceutical delivery systems. Trends in Food Science \& Technology, 17(5), 272-283. http://dx.doi.org/10.1016/j.tifs.2005.12.011.

Croguennec, T., Tavares, G. M., \& Bouhallab, S. (2016). Heteroprotein complex coacervation: A generic process. Advances in Colloid and Interface Science. http:// dx.doi.org/10.1016/j.cis.2016.06.009.

de Boer, A., Urlings, M. J. E., \& Bast, A. (2016). Active ingredients leading in health claims on functional foods. Journal of Functional Foods, 20, 587-593. http://dx. doi.org/10.1016/j.jff.2015.11.025.

Diaz, J. (2013). How to clean up your label. The World of Food Ingredients, April/May, $10,12,14,16$. Retrieved from http://repository.tudelft.nl/view/tno/uuid\% 3Ae64e9331-2e20-4caf-92e1-6d47b6be35f2/.

Farnaud, S., \& Evans, R. W. (2003). Lactoferrin-a multifunctional protein with antimicrobial properties. Molecular Immunology, 40(7), 395-405. http://dx.doi. org/10.1016/S0161-5890(03)00152-4.

Flanagan, S. E., Malanowski, A. J., Kizilay, E., Seeman, D., Dubin, P. L., Donato-Capel, L., ... Schmitt, C. (2015). Complex equilibria, speciation, and heteroprotein coacervation of lactoferrin and $\beta$-lactoglobulin. Langmuir, 31(5), 1776-1783. http://dx.doi.org/10.1021/la504020e.

Garti, N., \& McClements, D. J. (2012). Encapsulation technologies and delivery systems for food ingredients and nutraceuticals. Elsevier.

Gazzali, A. M., Lobry, M., Colombeau, L., Acherar, S., Azaïs, H., Mordon, S., ... Frochot, C. (2016). Stability of folic acid under several parameters. European Journal of Pharmaceutical Sciences, 93, 419-430. http://dx.doi.org/10.1016/j. ejps.2016.08.045.

Gouin, S. (2004). Microencapsulation: Industrial appraisal of existing technologies and trends. Trends in Food Science E Technology, 15(7-8), 330-347. http://dx.doi. org/10.1016/j.tifs.2003.10.005.

Gregory, J. F. (2001). Case study: Folate bioavailability. The Journal of Nutrition, 131(4 Suppl), 1376S-1382S.

Herrmann, W., \& Obeid, R. (2011). Vitamins in the prevention of human diseases. Berlin, Boston: De Gruyter. Retrieved from https://www.degruyter.com/view/ product/176599.

Hirakawa, K., Suzuki, H., Oikawa, S., \& Kawanishi, S. (2003). Sequence-specific DNA damage induced by ultraviolet A-irradiated folic acid via its photolysis product. Archives of Biochemistry and Biophysics, 410(2), 261-268. http://dx.doi.org/ 10.1016/S0003-9861(02)00722-1.

Jamil Akhtar, M., Ataullah Khan, M., \& Ahmad, I. (2003). Identification of photoproducts of folic acid and its degradation pathways in aqueous solution. Journal of Pharmaceutical and Biomedical Analysis, 31(3), 579-588. http://dx.doi. org/10.1016/S0731-7085(02)00724-0.

Liang, L., \& Subirade, M. (2010). B-Lactoglobulin/folic acid complexes: Formation, characterization, and biological implication. The Journal of Physical Chemistry B, 114(19), 6707-6712. http://dx.doi.org/10.1021/jp101096r.

Liang, L., Zhang, J., Zhou, P., \& Subirade, M. (2013). Protective effect of ligandbinding proteins against folic acid loss due to photodecomposition. Food Chemistry, 141(2), 754-761, http://dx doi.org/10.1016/j.foodchem.2013.03.044.

Loch, J. I., Bonarek, P., Polit, A., Riès, D., Dziedzicka-Wasylewska, M., \& Lewiński, K. (2013). Binding of 18-carbon unsaturated fatty acids to bovine $\beta$-lactoglobulinStructural and thermodynamic studies. International Journal of Biological Macromolecules, 57, 226-231. http://dx.doi.org/10.1016/j.ijbiomac.2013.03.021.

Lucock, M. (2000). Folic acid: Nutritional biochemistry, molecular biology, and role in disease processes. Molecular Genetics and Metabolism, 71(1-2), 121-138. http://dx.doi.org/10.1006/mgme.2000.3027.

Mandalari, G., Adel-Patient, K., Barkholt, V., Baro, C., Bennett, L., Bublin, M., ... Mills, E. N. C. (2009). In vitro digestibility of beta-casein and beta-lactoglobulin under simulated human gastric and duodenal conditions: A multi-laboratory evaluation. Regulatory Toxicology and Pharmacology: RTP, 55(3), 372-381. http://dx.doi.org/10.1016/j.yrtph.2009.08.010.

Matalanis, A., Jones, O. G., \& McClements, D. J. (2011). Structured biopolymer-based delivery systems for encapsulation, protection, and release of lipophilic compounds. Food Hydrocolloids, 25(8), 1865-1880. http://dx.doi.org/10.1016/ j.foodhyd.2011.04.014.

McClements, D. J., Decker, E. A., Park, Y., \& Weiss, J. (2009). Structural design principles for delivery of bioactive components in nutraceuticals and functional foods. Critical Reviews in Food Science and Nutrition, 49(6), 577-606. http://dx. doi.org/10.1080/10408390902841529.

McNulty, H., \& Pentieva, K. (2004). Folate bioavailability. Proceedings of the Nutrition Society, 63(4), 529-536. http://dx.doi.org/10.1079/PNS2004383.

Mills, J. L., \& Signore, C. (2004). Neural tube defect rates before and after food fortification with folic acid. Birth Defects Research Part A: Clinical and Molecular Teratology, 70(11), 844-845. http://dx.doi.org/10.1002/bdra.20075.

Off, M. K., Steindal, A. E., Porojnicu, A. C., Juzeniene, A., Vorobey, A., Johnsson, A., \& Moan, J. (2005). Ultraviolet photodegradation of folic acid. Journal of Photochemistry and Photobiology B: Biology, 80(1), 47-55. http://dx.doi.org/ 10.1016/j.jphotobiol.2005.03.001.
Patring, J. D. M., \& Jastrebova, J. A. (2007). Application of liquid chromatographyelectrospray ionisation mass spectrometry for determination of dietary folates: Effects of buffer nature and mobile phase composition on sensitivity and selectivity. Journal of Chromatography. A, 1143(1-2), 72-82. http://dx.doi.org/ 10.1016/j.chroma.2006.12.079.

Patro, B. S., Adhikari, S., Mukherjee, T., \& Chattopadhyay, S. (2005). Possible role of hydroxyl radicals in the oxidative degradation of folic acid. Bioorganic $\mathcal{E}$ Medicinal Chemistry Letters, 15(1), 67-71. http://dx.doi.org/10.1016/j. bmcl.2004.10.038.

Penalva, R., Esparza, I., Agüeros, M., Gonzalez-Navarro, C. J., Gonzalez-Ferrero, C., \& Irache, J. M. (2015). Casein nanoparticles as carriers for the oral delivery of folic acid. Food Hydrocolloids, 44, 399-406. http://dx.doi.org/10.1016/ j.foodhyd.2014.10.004.

Pérez, O. E., David-Birman, T., Kesselman, E., Levi-Tal, S., \& Lesmes, U. (2014). Milk protein-vitamin interactions: Formation of beta-lactoglobulin/folic acid nanocomplexes and their impact on in vitro gastro-duodenal proteolysis. Food Hydrocolloids, 38, 40-47. http://dx.doi.org/10.1016/j.foodhyd.2013.11.010.

Reddy, I. M., Kella, N. K. D., \& Kinsella, J. E. (1988). Structural and conformational basis of the resistance of.beta.-lactoglobulin to peptic and chymotryptic digestion. Journal of Agricultural and Food Chemistry, 36(4), 737-741. http://dx. doi.org/10.1021/jf00082a015.

Saha, G. B. (2010). Fundamentals of nuclear pharmacy. Springer.

Santos, W. G., Scurachio, R. S., \& Cardoso, D. R. (2014). Photochemical behavior of Safranine-Riboflavin complex in the degradation of folic acid. Journal of Photochemistry and Photobiology A: Chemistry, 293, 32-39. http://dx.doi.org/ 10.1016/j.jphotochem.2014.07.010.

Schmitt, C., Sanchez, C., Desobry-Banon, S., \& Hardy, J. (1998). Structure and technofunctional properties of protein-polysaccharide complexes: A review. Critical Reviews in Food Science and Nutrition, 38(8), 689-753. http://dx.doi.org/ $10.1080 / 10408699891274354$.

Schmitt, C., \& Turgeon, S. L. (2011). Protein/polysaccharide complexes and coacervates in food systems. Advances in Colloid and Interface Science, 167(12), 63-70. http://dx.doi.org/10.1016/j.cis.2010.10.001

Shimoni, E. (2009). Chapter 23 - Nanotechnology for foods: Delivery systems. In Barbosa-Canovas, G. V., Mortimer, A., Lineback, D., Spiess, W., Buckle, K., \& Colonna, P. (Eds.), Global issues in food science and technology (pp. 411-424). San Diego: Academic Press. Retrieved from http://www.sciencedirect.com/science/ article/pii/B9780123741240000235.

Sneharani, A. H., Karakkat, J. V., Singh, S. A., \& Rao, A. G. A. (2010). Interaction of curcumin with $\beta$-lactoglobulin-Stability, spectroscopic analysis, and molecular modeling of the complex. Journal of Agricultural and Food Chemistry, 58(20), 11130-11139. http://dx.doi.org/10.1021/jf102826q.

Tavares, G. M., Croguennec, T., Carvalho, A. F., \& Bouhallab, S. (2014). Milk proteins as encapsulation devices and delivery vehicles: Applications and trends. Trends in Food Science $\mathcal{E}$ Technology, 37(1), 5-20. http://dx.doi.org/10.1016/j. tifs.2014.02.008.

Tavares, G. M., Croguennec, T., Hamon, P., Carvalho, A. F., \& Bouhallab, S. (2015) Selective coacervation between lactoferrin and the two isoforms of $\beta$ lactoglobulin. Food Hydrocolloids, 48, 238-247. http://dx.doi.org/10.1016/ j.foodhyd.2015.02.027.

Tavares, G. M., Croguennec, T., Lê, S., Lerideau, O., Hamon, P., Carvalho, A. F., \& Bouhallab, S. (2015). Binding of folic acid induces specific self-aggregation of lactoferrin: Thermodynamic characterization. Langmuir: The ACS Journal of Surfaces and Colloids, 31(45), 12481-12488, http://dx.doi.org/10.1021/acs. langmuir.5b02299.

Teng, Z., Li, Y., \& Wang, Q. (2014). Insight into curcumin-loaded $\beta$-lactoglobulin nanoparticles: Incorporation, particle disintegration, and releasing profiles. Journal of Agricultural and Food Chemistry, 62(35), 8837-8847. http://dx.doi.org/ $10.1021 /$ jf503199g.

Thomas, A. H., Suárez, G., Cabrerizo, F. M., Martino, R., \& Capparelli, A. L. (2000). Study of the photolysis of folic acid and 6-formylpterin in acid aqueous solutions. Journal of Photochemistry and Photobiology A: Chemistry, 135(2-3), 147-154. http://dx.doi.org/10.1016/S1010-6030(00)00304-X.

Tripet, F. Y., \& Kesselring, U. W. (1975). The stability of folic acid in solid the state as a function of temperature and humidity. Pharmaceutica Acta Helvetiae, 50(10), 318-322.

Turgeon, S. L., Schmitt, C., \& Sanchez, C. (2007). Protein-polysaccharide complexes and coacervates. Current Opinion in Colloid E Interface Science, 12(4-5), 166-178. http://dx.doi.org/10.1016/j.cocis.2007.07.007.

Vora, A., Riga, A., Dollimore, D., \& Alexander, K. S. (2002). Thermal stability of folic acid. Thermochimica Acta, 392-393, 209-220. http://dx.doi.org/10.1016/S00406031(02)00103-X.

Yan, Y., Kizilay, E., Seeman, D., Flanagan, S., Dubin, P. L., Bovetto, L., ... Schmitt, C. (2013). Heteroprotein complex coacervation: Bovine $\beta$-lactoglobulin and lactoferrin. Langmuir, 29(50), 15614-15623. http://dx.doi.org/10.1021/ la4027464.

Zorilla, R., Liang, L., Remondetto, G., \& Subirade, M. (2011). Interaction of epigallocatechin-3-gallate with $\beta$-lactoglobulin: Molecular characterization and biological implication. Dairy Science \& Technology, 91(5), 629. http://dx. doi.org/10.1007/s13594-011-0036-3. 